\title{
Emerging therapies against infections with Pseudomonas
}

\section{aeruginosa [version 1; peer review: 2 approved]}

\author{
Burkhard Tümmler (iD1-3
}

\author{
${ }^{1}$ Clinical Research Group 'Molecular Pathology of Cystic Fibrosis' and 'Pseudomonas Genomics', Clinic for Pediatric Pneumology, \\ Allergology and Neonatology, Hannover Medical School, Hannover, 30625, Germany \\ ${ }^{2}$ Biomedical Research in Endstage and Obstructive Lung Disease (BREATH), German Center of Lung Disease, Hannover, 30625, \\ Germany \\ ${ }^{3}$ Cluster of Excellence RESIST (EXC 2155), Hannover Medical School, Hannover, 30625, Germany
}

V1 First published: 07 Aug 2019, 8(F1000 Faculty Rev):1371
https://doi.org/10.12688/f1000research.19509.1

Latest published: 07 Aug 2019, 8(F1000 Faculty Rev):1371

https://doi.org/10.12688/f1000research.19509.1

\section{Abstract}

Infections with Pseudomonas aeruginosa have been marked with the highest priority for surveillance and epidemiological research on the basis of parameters such as incidence, case fatality rates, chronicity of illness, available options for prevention and treatment, health-care utilization, and societal impact. P. aeruginosa is one of the six ESKAPE pathogens that are the major cause of nosocomial infections and are a global threat because of their capacity to become increasingly resistant to all available antibiotics. This review reports on current preclinical and clinical advances of anti-pseudomonal therapies in the fields of drug development, antimicrobial chemotherapy, vaccines, phage therapy, non-bactericidal pathoblockers, outer membrane sensitizers, and host defense reinforcement.

\section{Keywords}

Pseudomonas aeruginosa, antibiotic, ß-lactam inhibitor, vaccine, phage therapy

\section{Open Peer Review}

Approval Status

1

2

version 1

07 Aug 2019

Faculty Reviews are review articles written by the prestigious Members of Faculty Opinions. The articles are commissioned and peer reviewed before publication to ensure that the final, published version is comprehensive and accessible. The reviewers who approved the final version are listed with their names and affiliations.

1. José Luis Martinez-Menendez, CNB Spanish National Centre for Biotechnology, Madrid, Spain

2. Antonio Oliver, Instituto de Investigación Sanitaria Illes Balears (IdISBa), Palma de Mallorca, Spain

Any comments on the article can be found at the end of the article. 
Corresponding author: Burkhard Tümmler (tuemmler.burkhard@mh-hannover.de)

Author roles: Tümmler B: Conceptualization, Writing - Original Draft Preparation, Writing - Review \& Editing

Competing interests: No competing interests were disclosed.

Grant information: Work in the author's laboratory is supported by the Deutsche Forschungsgemeinschaft (DFG) (Collaborative Research Centre 900, projects A2 and Z1, grant 158989968; Germany's Excellence Strategy - EXC 2155 "RESIST" - project ID 39087428) and the Bundesministerium für Bildung und Forschung (BMBF) (German Center for Lung Research, Disease Area Cystic Fibrosis at BREATH, grant 82DZL002A1).

The funders had no role in study design, data collection and analysis, decision to publish, or preparation of the manuscript.

Copyright: @ 2019 Tümmler B. This is an open access article distributed under the terms of the Creative Commons Attribution License, which permits unrestricted use, distribution, and reproduction in any medium, provided the original work is properly cited.

How to cite this article: Tümmler B. Emerging therapies against infections with Pseudomonas aeruginosa [version 1; peer review: 2 approved] F1000Research 2019, 8(F1000 Faculty Rev):1371 https://doi.org/10.12688/f1000research.19509.1

First published: 07 Aug 2019, 8(F1000 Faculty Rev):1371 https://doi.org/10.12688/f1000research.19509.1 
In humans, the aquatic gamma-proteobacterium Pseudomonas aeruginosa may cause multiple infections that vary from local to systemic and from benign to life-threatening. The management of the severe ocular ${ }^{1}$ and burn $^{2}$ infections has made substantial progress during the last 20 years, but pneumonia and sepsis, particularly of ventilated patients in intensive care units (ICUs), are still burdened with high morbidity and lethality ${ }^{3,4}$. Chronic airway infections with $P$. aeruginosa are a major co-morbidity in patients with cystic fibrosis $(\mathrm{CF})^{5}$, bronchiectasis $^{6}$, or chronic obstructive pulmonary disease $(\mathrm{COPD})^{7}$.

Infections with $P$. aeruginosa have been marked with the highest priority for surveillance and epidemiological research on the basis of parameters such as incidence, case fatality rates, chronicity of illness, available options for prevention and treatment, health-care utilization, and societal impact ${ }^{8}$. $P$. aeruginosa is one of the six ESKAPE pathogens that are the major cause of nosocomial infections in the US and are a threat all over the world because of their capacity to become increasingly resistant to all available antibiotics ${ }^{9}$. $P$. aeruginosa is equipped with a lowly permeable outer membrane and multiple transport systems, rendering it naturally resistant to many antimicrobial agents ${ }^{10}$. In addition to its intrinsic resistance common to all $P$. aeruginosa, the bacterium has the extraordinary capacity to develop resistance to nearly all available antimicrobials ${ }^{11}$. The most common underlying mechanisms in multidrug-resistant (MDR) and extensively drug-resistant (XDR) $P$. aeruginosa are alterations in porin channels, efflux pumps, target modifications, and $\beta$-lactamases (for example, AmpC and carbapenemases) ${ }^{12,13}$. Resistance may be acquired by the selection of mutations in chromosomal genes or horizontal uptake of resistance determinants. Of particular concern are mobile genomic islands and integrons encoding carbapenemases or extendedspectrum $\beta$-lactamases (ESBLs) frequently co-transferred with aminoglycoside-modifying enzyme determinants ${ }^{14,15}$.

This review deals with the current approaches to develop new modes of anti-pseudomonal therapies. The decision of major pharmaceutical companies to exit antibacterial research has triggered the formation of non-profit alliances that support academia, clinicians, and industry in the development of novel antimicrobials. For example, Combating Antibiotic Resistant Bacteria (CARB-X) (https://carb-X.org/) is funded by the US Department of Health and Human Services, the National Institutes of Health, the Wellcome Trust, the Bill \& Melinda Gates Foundation, and Germany's Federal Ministry of Education and Research. CARB-X is investing up to $\$ 550$ million (USD) from 2016 to 2021 to accelerate the development of innovative antibiotics and other therapeutics, vaccines, and rapid diagnostics to address drug-resistant bacterial infections. Several companies have received funds from CARB-X to develop antipseudomonal agents, namely inhibitors of virulence factors and antibiotic potentiators ${ }^{16}$. Support to develop novel drugs is also provided by the Innovative Medicines Initiative (IMI) funded jointly by the European Union and the European pharmaceutical industry. As described below, CARB-X and the IMI have been instrumental in speeding up the pre-clinical and clinical development of numerous anti-pseudomonal agents.

\section{Antibiotics}

Antimicrobial chemotherapy is still the cornerstone of antipseudomonal treatment in clinical practice. $P$. aeruginosa is a naturally MDR organism, which may explain its success in becoming one of the most frequent nosocomial pathogens. Environmental $P$. aeruginosa strains are commonly susceptible to broad-spectrum penicillins and cephalosporins, aminoglycosides, monobactams, carbapenems, and fluoroquinolones. Since the 1980s, the intravenous combination therapy of piperacillin or ceftazidime with an aminoglycoside has been the standard of care to treat severe infections with $P$. aeruginosa, but the emergence of resistant organisms, particularly in the settings of intensive care or chronic persistence in vulnerable patient populations, has called for alternatives.

One strategy for the treatment of MDR $P$. aeruginosa has been the revival of colistin and polymyxin $\mathrm{B}$, old drugs that had been abandoned for many years because of their significant toxicity and side effects. Within a few years of more active therapeutic use, a growing number of strains have meanwhile developed resistance against these last-line peptide antibiotics $^{17,18}$. Mutations in various two-component systems activate the arn operon, which modifies the lipid A moiety of the lipopolysaccharide (LPS) through the addition of 4-amino-4-deoxy-L-arabinose, thereby rendering the bacterial cell resistant to the peptide antibiotic ${ }^{17,18}$.

An alternative strategy has been the development of molecules that overcome $\beta$-lactam antibiotic resistance. Two new cephalosporin- $\beta$-lactamase inhibitor combinations have recently been introduced into the clinic: ceftazidime-avibactam and ceftolozane-tazobactam ${ }^{19}$. Avibactam readily inactivates the chromosomal $\beta$-lactamase of $P$. aeruginosa AmpC. Tazobactam is a less potent inhibitor of AmpC but this is compensated by the new antibiotic component in this combination, ceftolozane, which is only poorly hydrolyzed by AmpC.

At the time of this writing, more than $90 \%$ of $P$. aeruginosa isolates around the world seem to be susceptible to colistin, ceftazidime-avibactam, and ceftolozane-tazobactam ${ }^{15,20-23}$. Resistance to the latter two antibiotic-antibiotic inhibitor combinations has been observed mainly in $P$. aeruginosa isolates that belong to the pandemic ST235 high-risk clone and carry novel isoforms of AmpD or ESBLs or both ${ }^{24,25}$.

Besides avibactam and tazobactam, other $\beta$-lactamase inhibitors-that is, relebactam ${ }^{26-29}$, zidebactam ${ }^{30,31}$, nacubactam ${ }^{32}$, vaborbactam $^{28}$, VNRX-5133 $3^{33}$, and AAI101 ${ }^{26}$ - are being tested in clinical trials.

An encouraging addition to the portfolio of anti-pseudomonal $\beta$-lactams is the siderophore cephalosporin cefiderocol ${ }^{34,35}$. Cefiderocol is structurally related to the cephalosporins ceftazidime and cefepime by sharing side chains that block recognition and inhibit hydrolysis by $\beta$-lactamases. The novelty resides in the extension of one side chain by a catechol 2-chloro-3,4-dihydroxybenzoic acid moiety. The catechol side chain enables ferric iron ion binding. The cefiderocol iron ion 
complex is recognized by active iron transport systems (such as PiuA) which transport cefiderocol across the outer membrane and to the periplasmic space $^{36}$. After dissociation of the complex, cefiderocol binds to penicillin binding proteins (PBP1a, PBP1b, PBP2, and PBP3) and inhibits peptidoglycan synthesis, causing cell death. Compared with the anti-pseudomonal agents that are currently available for use in humans, cefiderocol had the strongest activity against MDR $P$. aeruginosa strains. Of all $\beta$-lactams, cefiderocol has the most extended stability to hydrolysis by $\beta$-lactamases and its periplasmic entry via active iron transport systems overcomes $\beta$-lactam resistance associated with outer membrane permeability mutations in P. aeruginosa ${ }^{37}$.

Cefiderocol is more potent in vitro against MDR $P$. aeruginosa than ceftazidime-avibactam and ceftolozane-tazobactam ${ }^{38}$. Cefiderocol showed activity against AmpC-overproducing strains, low affinity for chromosomal AmpC $\beta$-lactamases, and a low propensity of temporal induction of AmpC $\beta$-lactamases of $P$. aeruginos $a^{39}$. Cefiderocol is active against carbapenemnon-susceptible isolates, including serine carbapenemase- and metallo- $\beta$-lactamase-producing strains ${ }^{40,41}$.

Carbapenem-resistant Gram-negative bacteria represent the highest priority for addressing global antibiotic resistance. Cefiderocol may address this problem-at least for some years to come. A recently completed phase II clinical trial demonstrated clinical efficacy and safety of intravenous cefiderocol compared with imipenem/cilastatin in patients with complicated urinary tract infections ${ }^{35}$. Clinical trials of hospital-acquired pneumonia and carbapenem-resistant infections (ClinicalTrials.gov identifiers NCT02321800, NCT02714595, and NCT03032380) are ongoing.

Novel non- $\beta$-lactam antimicrobials have also been developed to target MDR organisms ${ }^{42}$. Plazomicin is a sisomycin derivative that is unaffected by aminoglycoside-modifying enzymes. It was approved by the US Food and Drug Administration (FDA) for use in adults with complicated urinary tract infections. Its anti-pseudomonal activity is comparable to that of amikacin and less potent than that of tobramycin, indicating that this compound will probably not be very useful for the treatment of infections with $P$. aeruginos $a^{42}$. The same argument applies even more so to the tetracyclines eravacycline and omadacyline, which demonstrate antimicrobial activity against many Gram-positive and Gram-negative bacteria but are not active against $P$. aeruginosa $a^{42}$. In contrast, two novel fluoroquinolones, finafloxacin ${ }^{43,44}$ and delafloxacin ${ }^{44,45}$, which (depending on $\mathrm{pH}$ ) exert anti-pseudomonal activity equivalent to or higher than that of ciprofloxacin, have recently become available.

Besides these analogues of classes of antimicrobials well known for their basic chemical structure and mode of antimicrobial action, anti-pseudomonal drugs that aim at a new target are being developed. Murepavadin, a 14-amino acid synthetic peptidomimetic, is a first-in-class antibiotic targeting outer membrane protein ${ }^{46}$. During the biogenesis of the outer membrane, new LPS molecules are transported from their site of assembly on the inner membrane to the outer membrane by seven LPS transport proteins (LptA-G). The complex formed between the outer membrane protein LptD and the lipoprotein LptE is responsible for transporting LPS from the periplasmic side of the outer membrane to its final location on the cell surface. Murepavadin inhibits the LPS transport protein LptD in $P$. aeruginosa. Murepavadin was proven to be a very potent antibiotic highly specific to $P$. aeruginosa, including carbapenemase producers and ceftolozane/tazobactam-resistant and colistin-resistant strains. Murepavadin $(96.7 \%$ of isolates susceptible) was more active than colistin (93.6\%), followed by ceftolozane/tazobactam (70.6\%) and tobramycin $(47.5 \%)^{47,48}$. Two clinical trials have been evaluating the efficacy and safety of murepavadin in treating lower respiratory tract infections caused by $P$. aeruginosa (suspected or confirmed) among patients with ventilation-associated pneumonia or bronchiectasis unrelated to $\mathrm{CF}$ (ClinicalTrials.gov identifiers NCT02096315 and NCT02096328, respectively). However, by July 17, 2019, the studies were stopped because an unexpectedly high frequency of renal failures had been observed in study participants who had received murepavadin. The development of an aerosolized formulation of murepavadin for a topical application will not be affected by this decision.

Murepavadin is a specific weapon against $P$. aeruginosa, which sets it apart from the large pipeline of natural and synthetic antimicrobial peptides that act against multiple taxa, including $P$. aeruginosa. Several novel peptides with broad antimicrobial activity-for example, DGL13K ${ }^{49}, \mathrm{Mel}^{50}$, melimine ${ }^{50}$, cecropin $\mathrm{B}^{51}$, LBP-2 ${ }^{52,53}$, Pse-T2 ${ }^{54}$, 6K-F17 $7^{55}, \mathrm{MDP}^{56}$, and $\mathrm{MDP}^{56}$ - have recently been described.

Aerosolized anti-pseudomonal agents are the domain for the treatment of chronic airway infections of individuals with $\mathrm{CF}$ or bronchiectasis. Established options are the long-term inhalation with high-dose tobramycin ${ }^{57,58}$, colistin ${ }^{59-61}$, or aztreonam-lysine ${ }^{62-64}$. Emerging alternatives were the inhalation of liposomal amikacin ${ }^{65}$ and, more recently, the inhalation with dry powder ${ }^{66,67}$ or liposomal ${ }^{68,69}$ ciprofloxacin or with liposomal levofloxacin ${ }^{70}$. As described below, the clinical drug development programs had to face unforeseen obstacles unrelated to the proven anti-pseudomonal activity of the formulations in vitro.

Liposomal amikacin can penetrate within airway secretions and within $P$. aeruginosa biofilms, making it an attractive therapeutic option for chronic pulmonary infections. A phase II study with once-daily liposomal amikacin demonstrated acute tolerability, safety, biologic activity, and efficacy in CF patients with $P$. aeruginosa infection ${ }^{71}$. However, apparently because of the results of a long-term rat inhalation carcinogenicity study, the FDA placed a clinical hold on the phase III clinical trials with this patient cohort by August 2017 and requested more safety data. Thirteen months later, the FDA approved inhalation with liposomal amikacin for the treatment of lung disease with Mycobacterium avium complex (MAC) in patients with refractory disease. Thus, at least until the time of this writing, the journey ended with a new therapy for MAC but not for $P$. aeruginosa. 
Two phase III, double-blind, placebo-controlled trialsRESPIRE $1^{67}$ and RESPIRE $2^{66}$-examined the efficacy and safety of ciprofloxacin dry powder for inhalation (DPI) in patients with non-CF bronchiectasis who had experienced two or more exacerbations in the previous year and pre-defined bacteria in sputum, including $P$. aeruginosa, as a major pathogen. These two trials represent the largest clinical trial program ever conducted in bronchiectasis. RESPIRE 1 largely enrolled across Europe, North and South America, Australia, and Japan, whereas RESPIRE 2 focused on Asia and Eastern Europe. Patients received twice-daily ciprofloxacin DPI $32.5 \mathrm{mg}$ or placebo in 14- or 28-day on/off treatment cycles for 48 weeks. The 14-day on/off treatment cycles in RESPIRE 1 significantly prolonged time to first exacerbation and reduced the frequency of exacerbations. The same trends were seen in the 14-day cycle in RESPIRE 2 and the 28-day cycles but did not achieve significance. When the data were pooled, an average $24 \%$ reduction in exacerbations was calculated. Experts who commented on the outcome of the trials concluded that aerosolized dry powder ciprofloxacin is most likely to be of benefit in selected patients with poorly controlled disease and very frequent exacerbations ${ }^{72}$.

An alternative formulation to dry powder is the encapsulation of drug into liposomes. Two randomized, double-blind, placebo-controlled, phase 3 trials-ORBIT-3 and ORBIT-4investigated the safety and efficacy of inhaled liposomal ciprofloxacin $^{69}$. The more than 500 study participants had had two or more pulmonary exacerbations treated with antibiotics in the prior 12 months, had non-CF bronchiectasis, and had a history of chronic $P$. aeruginosa lung infection. Compared with placebo, inhalation with liposomal ciprofloxacin led to a significantly longer median time to first pulmonary exacerbation in the ORBIT-4 but not in the ORBIT-3 trial. In a pooled analysis of data from the two trials, median times to first pulmonary exacerbation were 157 days in the placebo group and 222 days in the verum group, a non-statistically significant difference of 65 days $(0.82,95 \%$ confidence interval $(\mathrm{CI}) 0.65-1.02 ; P=0.074)$.

For both the two RESPIRE and ORBIT trials, the results were not replicated. The discrepant outcome was attributed to differences in clinical practice and the vast ethnic, geographic, and endo-phenotypic heterogeneity of bronchiectasis ${ }^{72}$. Future trials should address these differences across the globe and should thoroughly characterize the endo-phenotype of individual patients in order to identify the patient groups which benefit from specific modes of anti-pseudomonal treatment. Patient stratification within this highly heterogeneous group of patients makes sense in light of the experience with $\mathrm{CF}$, which is a monogenic disorder of Caucasians. Most clinical studies on anti-pseudomonal chemotherapy in this more homogeneous patient population met their primary endpoints with smaller cohorts than the RESPIRE and ORBIT trials.

In randomized controlled trials, monotherapy with an aerosolized anti-pseudomonal drug has been proven to be an effective measure to suppress chronic airway infections with P. aeruginosa in CF. Comparable data on inhaled combination therapy are still missing. $P$. aeruginosa biofilms grown in vitro typically consist of a stalk-forming subpopulation situated in the deeper layer with low metabolic activity and a cap-forming subpopulation in the upper layer with metabolically active cells $^{73}$. Colistin preferentially kills the stalk subpopulation, whereas the cap-forming subpopulation is susceptible to the aminoglycoside tobramycin ${ }^{74}$. Owing to this observation in biofilms as models for the sessile lifestyle of $P$. aeruginosa in $\mathrm{CF}$ airways, the sequential therapy with inhaled tobramycin and colistin was examined in an observational study with $41 \mathrm{CF}$ patients with chronic $P$. aeruginosa infection ${ }^{75}$. Treatment was well tolerated and significantly improved patients' lung function. An alternative to colistin-tobramycin may be aztreonamtobramycin. When biofilms were grown in flow cells, the alternation of tobramycin and aztreonam potentiated the bactericidal effect and the reduction in bacterial biomass ${ }^{76}$.

Meanwhile, combination inhalation therapy has become routine in clinical practice, but besides the open-label exploratory study mentioned above, no clinical trials have yet been published. More clinical data about the efficacy of systemic combination therapy are available. For example, an 11-year single-center retrospective analysis of the treatment of $P$. aeruginosa bloodstream infections revealed that survival of patients receiving combination therapy ( $\beta$-lactam-aminoglycoside or $\beta$-lactamquinolone) was significantly higher than that of patients receiving $\beta$-lactam monotherapy ${ }^{77}$. A recently published metaanalysis compared the outcome of empirical non-optimized double $\beta$-lactam combination therapy versus $\beta$-lactam plus aminoglycoside $^{78}$. In the 164 cases from 13 randomized clinical trials reported between 1972 and 1993, a response to $P$. aeruginosa was achieved in $58.5 \%$ for double $\beta$-lactam and $60.6 \%$ for $\beta$-lactam-aminoglycoside. The two regimens achieved similar clinical and microbiological responses, but nephrotoxicity and ototoxicity were significantly lower with double $\beta$-lactam combination therapy. These metadata are from a time period before broad-spectrum antibiotics were widely introduced into the clinic. Nevertheless, they tell us that double $\beta$-lactams may be a useful therapeutic option because synergy may arise from the complementary inactivation of sets of PBPs.

\section{Modulators of bacterial cell wall, transport, signaling, or virulence}

Mucoid alginate-overproducing $P$. aeruginosa strains are a phenotypical hallmark of chronic airway infections in individuals with CF. Bacterial alginate is made of alternating blocks of mannuronate homooligomers and mannuronate-guluronate heterooligomers, whereas the algal alginate also contains guluronate homooligomers. Algal-derived alginate oligomers enriched in guluronate homooligomers (oligoG) reduce the viscosity of sticky biofilms and potentiate anti-bacterial and anti-fungal compounds. OligoG DPI is being tested in IMIsupported phase 2 clinical trials whether they improve lung function and respiratory symptoms in patients with CF.

The intrinsic multidrug resistance of $P$. aeruginosa is partly based on its low outer membrane permeability. By 1983, Vaara and 
Vaara introduced the concept of outer membrane-disorganizing sensitizers that make the outer membrane more permeable to amphiphilic and hydrophobic compounds ${ }^{79}$. For example, the non-bactericidal polymyxin $\mathrm{B}$ nonapeptide sensitized $P$. aeruginosa strains 2 - to 40 -fold to ciprofloxacin, norfloxacin, and ofloxacin and 80- to 200-fold to the parent compound nalidixic acid, indicating that the higher antipseudomonal activity of fluoroquinolones compared with nalidixic acid was based not only on the more efficient inhibition of the DNA gyrase but also on a higher outer membrane permeability ${ }^{80}$. Now more than 30 years after the first report of three outer membrane sensitizers, the approved anti-protozoal drug pentamidine ${ }^{81}$ and the polymyxin B analogues SPR206 and SPR $741^{82,83}$ are in pre-clinical and clinical studies to re-fuel the anti-Pseudomonas pipeline.

P. aeruginosa uses quorum sensing, including the elastase (Las), rhamnolipid (Rhl), and Pseudomonas quinolone signal (PQS) systems, to regulate and coordinate population-wide group behaviors in infection processes like biofilm formation and the concerted secretion of virulence factors. Pathoblockers of the quorum sensing system abolish pathogenic features without affecting cell viability, providing the basis for a lower druginduced selection pressure ${ }^{84-87}$. Potent inhibitors of all known quorum sensing systems have been identified, but none of the novel compounds such as NX-As-401 (www.neembiotech. com) has yet made it into clinical trials. The exceptions are the well-known macrolide antibiotics. In the late 1980s, Japanese physicians reported that the chronic administration of erythromycin, clarithromycin, and azithromycin improved the clinical symptoms and prognosis of patients with chronic $P$. aeruginosa infections ${ }^{88}$. Azithromycin does not kill $P$. aeruginosa but inhibits protein biosynthesis and quorum sensing ${ }^{89}$. Azithromycin is now widely used for the treatment of chronic airway infections with $P$. aeruginosa in patients with COPD, bronchiectasis, or CF. Within the setting of the ICU, azithromycin showed a trend to prevent ventilation-associated pneumonia in intubated patients and significantly reduced the activation of quorum sensing-regulated virulence traits ${ }^{90}$.

Iron metabolism is another highly topical target of anti-pseudomonal drug development. Gallium is an iron mimetic ${ }^{91-95} \cdot \mathrm{Ga}^{3+}$ has an ionic radius nearly identical to that of ferric iron $\mathrm{Fe}^{3+}$ and hence can replace iron in $\mathrm{Fe}^{3+}$-dependent biological systems. Unlike $\mathrm{Fe}^{3+}, \mathrm{Ga}^{3+}$ is not reduced under physiological conditions and thus inactivates iron-mediated redox cycling ${ }^{91-93}$. Gallium inhibited $P$. aeruginosa growth and biofilm formation and killed planktonic and biofilm bacteria in vitro ${ }^{91,92,94}$ and increased survival in a murine infection model ${ }^{91,92,95}$. Intravenous gallium treatment improved lung function in $\mathrm{CF}$ patients with chronic $P$. aeruginosa lung infection in a preliminary phase 1 clinical trial ${ }^{95}$.

Neutralization of virulence effectors is another currently pursued approach to combat infections with $P$. aeruginosa. Some programs are supported by the CARB-X alliance. For example, inhibitors are developed against the P. aeruginosa LasB elastase (https://antabio.com/programs), thereby targeting the bacterium's ability to evade the immune system and cause disease and, when given alongside antibiotics, helping to clear $P$. aeruginosa infections. Other programs have focused on the machinery and virulence effectors of the type III secretion system. Phenoxyacetamide inhibitors target the needle protein $\mathrm{PscF}$ that delivers the virulence effectors into the host cell ${ }^{96,97}$. Alternatively, monoclonal antibodies were generated against the PcrV protein that forms the tip of the injectosome complex ${ }^{98}$. Intravenous KB001-A, an anti-PcrV PEGylated monoclonal antibody fragment, showed limited efficacy in CF patients infected with P. aeruginos $a^{99}$. The repeated administration of KB001-A over 16 weeks was associated with a small improvement of lung function and decrease of sputum inflammatory markers but did not prolong the time-to-need for antibiotics for worsening respiratory signs and symptoms ${ }^{100}$. Bispecific antibodies that block multiple evasion and subversion mechanisms in tandem may be more efficacious ${ }^{101}$. In a murine bacteremic model of $P$. aeruginosa infection, the bispecific therapeutic antibody MEDI3902, targeting PcrV and the Psl exopolysaccharide, was shown to efficiently enhance neutrophil uptake, phagosome acidification, and bacterial killing ${ }^{101}$. After completion of a phase 1 study ${ }^{102}$, passive immunization with MEDI3902 (renamed Gremubamab) is currently in phase 2b development for prevention of nosocomial $P$. aeruginosa pneumonia in patients undergoing mechanical ventilation (EVADE study funded by the IMI).

\section{Novel formulations for anti-pseudomonal drug delivery}

Impaired penetration of antimicrobials through bacterial biofilms is one of the reasons for the failure of anti-pseudomonal therapy of burn wounds and chronic lung infections. Encapsulation of antimicrobials in nanocarriers may facilitate drug diffusion within the sticky biofilm matrix, protect the drug from unwanted degradation, confer controlled drug release, and increase uptake by the drug target. Anti-pseudomonal drugs such as ciprofloxacin ${ }^{103-105}$, meropenem ${ }^{106}$, tobramycin ${ }^{107,108}$, gentamicin $^{109}$, or amikacin ${ }^{110}$ were encapsulated into liposomes or loaded into nanoparticles. The drug delivery systems were diverse in chemical nature and include anionic liposomes ${ }^{105,106,109}$, poly(lactic-co-glycolic) acid nanoparticles ${ }^{110,111}$, water-soluble chitosan oligosaccharide conjugates ${ }^{112}$, oil-in-water cross-linked polymeric nanocomposites ${ }^{113}$, graphen-oxide conjugates $^{107}$, or solid lipid nanoparticles ${ }^{114}$, to name just a few. Alternatively, dry powders $^{103,104,108,115}$ or hydrogels ${ }^{116-119}$ were formulated or wound dressings were coated with a topical antimicrobial such as silver oxynitrate $^{120}$. Irrespective of the chosen formulation, most published articles report that their formulation penetrates through mucus and biofilms, is more effective than the antimicrobial alone to eradicate biofilm formation, and mitigates infection and disease progression.

\section{Vaccines}

The provision of an effective vaccine to protect patient populations at risk from an infection with $P$. aeruginosa has been on the agenda of Pseudomonas researchers for many decades, but there are no licensed vaccines at present. In the 1990s, the Swiss Serum and Vaccine Institute developed an octavalent 
P. aeruginosa O-polysaccharide-toxin A conjugate vaccine for immunization of healthy $P$. aeruginosa-negative patients with $\mathrm{CF}^{121}$. The persistence of high-affinity antibodies among immunized patients correlated with a significantly lower rate of infection after 4 to 6 years of observation. The vaccine was well received by the European $\mathrm{CF}$ community. Patients at my $\mathrm{CF}$ center regularly travelled to Bern, Switzerland, to receive boosters every two to three years until the stock was used up. A few years later, Döring et al. conducted a double-blind, placebo-controlled, multicenter trial with a flagella vaccine demonstrating that active immunization of patients with $\mathrm{CF}$ lowers the risk for infection with $P$. aeruginosa ${ }^{122}$. The third approach was the 20-year-long development of vaccines based on OprF-OprI outer membrane fusion proteins as antigen ${ }^{123}$. In the last pilot study, published in 2010, human volunteers were vaccinated with a systemic, nasal, or oral live vaccine based on attenuated live Salmonella (strains CVD908 and Ty21a), followed by a systemic booster ${ }^{124}$. Systemic and mucosal vaccines induced a comparable rise of serum antibody titers, but only nasal and oral vaccinations elicited a significant rise of IgA and IgG antibodies in the lower airways. At that time, the authors concluded that nasal and oral OprF-OprI vaccines were promising candidates for development of anti-pseudomonal immunization through inducing a specific antibody response in the lung.

These old data, including small clinical trials on burns and $\mathrm{CF}$, provided evidence that a vaccine could be an effective measure to prevent infections with $P$. aeruginosa. Hence, the recombinant OprF-OprI vaccine was tested in a randomized, placebo-controlled, double-blind phase II/III study ${ }^{125}$, which was conducted in 800 mechanically ventilated ICU patients at 52 trial sites in six European countries. Patients were vaccinated twice with either the $P$. aeruginosa vaccine candidate or a placebo at a 7-day interval in conjunction with standard-ofcare treatments for ICU patients. Although the trial confirmed good immunogenicity and an acceptable safety profile of the vaccine candidate, the primary endpoint of the phase II/III trial was not met. Therefore, findings from a previous phase II study that had shown a strong reduction in all-cause mortality were not confirmed.

The outcome of this largest-ever trial performed on a Pseudomonas vaccine was disappointing. Nevertheless, there are encouraging new data on other antigens. For example, a live aroAaroB attenuated Salmonella vaccine that uses a fusion between the $P$. aeruginosa type III secretion antigen PcrV expressed under the control of the sseA promoter and the $S$. enterica type III secretion effector protein SseJ has been constructed ${ }^{126}$. Compared with control mice, mice immunized with attenuated Salmonella expressing this fusion had lower serum levels of pro-inflammatory cytokines and reduced bacterial loads in the spleen and lungs after $P$. aeruginosa infection. Importantly, in this model, immunized mice also showed significantly enhanced survival. Another novel strategy is the design of live-attenuated whole cell vaccines based on D-glutamate auxotrophy ${ }^{127}$. The enzyme glutamate racemase MurI converts the amino acid L-glutamate into its enantiomer D-glutamate, which is an essential component of peptidoglycan. In-frame deletion of the murI gene generated a live-attenuated $P$. aeruginosa auxotrophic strain that, upon local or systemic administration, triggered appropriate cellular immune responses and production of specific and cross-reactive antibodies in the vaccinated murine hosts and conferred long-term survival against lethal infections with $P$. aeruginosa but, on the other hand, was rapidly eliminated from the host without causing disease. Other groups showed protection in murine infection models by using the iron acquisition protein $\mathrm{HitA}^{128}$, PA5340 combined with PA3526-MotY ${ }^{129}$, PcrV with CpG oligodeoxynucleotide ${ }^{130}$, or the pilus proteins PilQ and PilA ${ }^{131}$ as vaccine antigens.

\section{Phage therapy}

Given that antibiotic resistance is an increasing threat not only to human health but also to the production of food and to sustainable development, phage therapy is regaining interest as an alternative or addition to antibiotic therapy for the treatment of bacterial infections ${ }^{132}$. Phage therapy was abandoned in many countries with the advent of antibiotic therapy but has been continually developed in Eastern European countries with centers in Warsaw, Poland, and Tbilisi, Georgia ${ }^{133}$. Shotgun metagenome sequencing revealed that the phage cocktails sold in pharmacies in Georgia and Russia contained antipseudomonal phages ${ }^{134}$. A few case reports from Belgium and the US communicated the successful treatment of infections with MDR $P$. aeruginosa ${ }^{135,136}$.

Early this year, the outcome of the first clinical study on phage therapy was reported ${ }^{137}$. The study, conducted as a randomized controlled double-blind trial, compared the tolerability and efficacy of a cocktail of lytic anti- $P$. aeruginosa bacteriophages with standard of care for patients with burns. The primary endpoint-the median time to sustained reduction in bacterial burden-was reached in 47 hours in the standard-of-care group (hazard ratio $0.29,95 \%$ CI $0.10-0.79 ; P=0.018$ ) versus 144 hours (95\% CI 48-not reached) in the group that received the phages. The finding that a standardized phage cocktail decreased bacterial burden in burn wounds more slowly than the standard of care is a strong indication that phage cocktails of fixed composition could unfavorably interfere with the evolutionary race between phage and bacterium by selecting phage resistance in the heterogeneous bacterial populations that vary from patient to patient. The personalized approach of choosing phages that specifically target the Pseudomonas bacteria in the individual host habitat may be more effective, although it will require rethinking of the regulatory agencies.

Research is very active in the pre-clinical arena. Practical themes are the setup of efficacious and safe antibacterial phage cocktails, the design of clever infection models, and the development of phages as adjuvants of antibiotic therapy. More importantly, if we want to make phage therapy a success, we need an in-depth understanding of how the mutual evolutionary race of attack and resistance between phage and bacterium takes place. Phages are, in principle, a smart anti-pseudomonal weapon. They specifically target a narrow spectrum of hosts, self-amplify, kill antibiotic-resistant strains, and have limited 
immunological effects in humans. However, it will not be a global anti-pseudomonal weapon. During chronic infection, $P$. aeruginosa may modify or delete all of its phage receptors. The author noticed that the majority of $P$. aeruginosa clones that persisted for five years or more in a $\mathrm{CF}$ lung had become pan-resistant to phages.

\section{Hygienic measures}

$P$. aeruginosa is responsible for a wide range of acquired infections in critically ill patients. Microbiological monitoring according to Clinical and Laboratory Standards Institute standards, antimicrobial stewardship, and infection control programs, including environmental cleaning and disinfection, hand hygiene, and education of personnel, have been demonstrated to prevent the development of resistance in $P$. aeruginosa $a^{138}$. Prophylactic antibiotic days and inadequate empiric antibiotic therapy are independent major risk factors for the emergence of MDR ventilator-associated pneumonia in the ICU ${ }^{139}$. Thus, prolonged exposure to unnecessary antibiotics should be avoided.

In the hospital setting, $P$. aeruginosa may contaminate sanitary facilities, humid medical devices, aqueous solutions, soaps, and detergents ${ }^{140}$. For example, recently published case reports identified sinks or flexible endoscopes as reservoirs for nosocomial transmission of $P$. aeruginosa $a^{141,142}$. Sinks in hospitals are regularly contaminated with $P$. aeruginosa. Opening of water taps generates aerosols containing $P$. aeruginosa sink organisms that contaminate the faucet and hands during hand washing ${ }^{140}$. Installation of filters under all water faucets has been shown to prevent bacterial contamination of tap water ${ }^{143}$.

In the context of $\mathrm{CF}$, patient-to-patient transmissions of $P$. aeruginosa were reported from $\mathrm{CF}$ clinics, summer camps, and rehabilitation centers ${ }^{5,144}$. Transmissible epidemic clones spread at CF clinics in Australia, Canada, Denmark, The Netherlands, and the $\mathrm{UK}^{5}$. Hence, infection prevention and control practices have been introduced into $\mathrm{CF}$ clinics encompassing education, temporal separation of $P$. aeruginosa-positive and $P$. aeruginosa-negative patients, hand and cough hygiene, and cleaning and disinfection of equipment ${ }^{145}$. Retrospective and prospective observational studies performed after the introduction of cohort segregation have demonstrated decreases in the numbers of prevalent and incident cases of epidemic $P$. aeruginosa infections ${ }^{5}$.

\section{Enhancement of host defense}

Active immunization of vulnerable patient groups is the classic approach to prevent microbial infection. But in real-life situations such as an acute illness requiring hospitalization, the time span to mount protective antibody titers may be too long to be clinically meaningful.

In the ICU, treatment with antibiotics often is live-saving but is also a major risk factor for subsequent nosocomial lung infection with $P$. aeruginosa. A recent study by Robak et al. demonstrates that the ICU patient's susceptibility to secondary Pseudomonas infection is caused by antibiotic-associated secondary IgA deficiency ${ }^{146}$. Depletion of the resident microbiota by broadspectrum antibiotic treatment inhibits the stimulation of pulmonary $\operatorname{IgA}$ production mediated by microbiota-dependent activation of Toll-like receptors and the tumor necrosis factor (TNF) family cytokine APRIL (a proliferation-inducing ligand). If antibiotic-pretreated mice received $\operatorname{IgA}$ by the nasal route, their antibacterial defense against $P$. aeruginosa was partially restored. The authors propose that ICU patients on broadspectrum antimicrobial therapy may benefit from prophylactic or therapeutic pulmonary IgA administration or both.

Cell-based treatment is another emerging option to target airway infections with $P$. aeruginos $a^{147}$. Therapeutic phagocytes such as macrophages can be produced from induced pluripotent stem cells (iPSCs) in industry-compatible, stirred-tank bioreactors. iPSC macrophages rescued mice from $P$. aeruginosamediated acute infections of the lower respiratory tract within 4 to 8 hours after intra-pulmonary transplantation and reduced bacterial load ${ }^{147}$. This type of cell therapy may become an option for the treatment of congenital or acquired immune deficiency.

\section{Conclusions}

The ESKAPE pathogens are the tip of the iceberg of the global antibiotic crisis. Many regions in the world now face infections with $P$. aeruginosa that is colistin- or carbapenem-resistant or both. Fortunately, the traditional approach to develop derivatives of validated scaffolds is still promising. The novel $\beta$-lactam inhibitors and siderophore cephalosporin are active against almost all current $P$. aeruginosa. The modification and combination of lead modules that tackle well-characterized bacterial targets constitute a rather safe approach to come up with an antimicrobial that will show efficacy and safety in clinical trials. The development of compounds against novel targets should be more rewarding in the long run. However, as we now experience with the currently most potent antipseudomonal agent, murepavadin ${ }^{47,48}$, the risk of off-target side effects is high and the compound may fail in clinical trials.

Pathoblockers have finally come of age ${ }^{81,84-87}$. Ten to forty years after the proof-of-principle experiments showing that small molecules may reduce fitness or virulence of $P$. aeruginosa without being bactericidal themselves were published ${ }^{79,98,148}$, the first sensitizers are now being examined in clinical studies $^{83}$. For example, the iron biomimetic gallium attacks $P$. aeruginosa at its metabolic achilles' heel ${ }^{91-95}$. The outcome of the first clinical study is encouraging ${ }^{95}$; however, we still do not know whether gallium will drive $P$. aeruginosa cells into an iron deficiency status that may promote the adverse production of virulence factors $^{149}$.

Given the threat of bacteria that are pan-resistant to the patient's $P$. aeruginosa isolates, phage therapy is re-emerging as an attractive alternative to treat infections with $P$. aeruginosa. The outcome of the first high-standard clinical trial, published earlier this year, taught us that predetermined phage cocktails will probably not be the solution ${ }^{137}$. Some $P$. aeruginosa strains will not be susceptible or will rapidly become resistant to the administered phages. To make phage therapy globally efficacious, we need a personalized approach as was recently demonstrated for a life-threatening infection with Mycobacterium abscessus $^{150}$. Phage cocktails should be formulated on a caseby-case basis to specifically target of phage therapy. However, phage therapy will leave its niche only if the regulatory agencies 
change the legal rules and permit personalized medicine on a large scale.

The development of antimicrobials is the classic approach to fight infections with $P$. aeruginosa. Only recently, the scientific community started to adopt the concept that the enhancement of host defense may be a promising alternative to conquer a nosocomial pathogen that causes severe infections in vulnerable populations but is more or less innocent for the healthy immunocompetent host. Relying on clinical experience in the ICU of the often disastrous course of secondary Pseudomonas pneumonias, researchers are becoming aware of the importance of the interplay between immune status and microbiome to contain this nosocomial pathogen ${ }^{146}$. The enhancement of innate and adaptive immunity is a promising approach to vanquish MDR and XDR $P$. aeruginosa. Bispecific therapeutic antibodies $^{101,102}$ and local transfer of isogenic iPSC-derived immune cells ${ }^{147}$ could become the weapons of the future to prevent the fatal outcome of $P$. aeruginosa pneumonia and sepsis in ICU patients.

\section{Abbreviations}

CARB-X, Combating Antibiotic Resistant Bacteria; CF, cystic fibrosis; CI, confidence interval; COPD, chronic obstructive pulmonary disease; DPI, dry powder for inhalation; ESBL, extended-spectrum $\beta$-lactamase; FDA, US Food and Drug Administration; ICU, intensive care unit; IMI, Innovative Medicines Initiative; iPSC, induced pluripotent stem cell; Las, elastase; LPS, lipopolysaccharide; Lpt, lipopolysaccharide transporting protein; MAC, Mycobacterium avium complex; MDR, multidrug-resistant; OligoG, oligomers enriched in guluronate homooligomers; $\mathrm{PBP}$, penicillin binding protein; XDR, extensively drug resistant

\section{Grant information}

Work in the author's laboratory is supported by the Deutsche Forschungsgemeinschaft (DFG) (Collaborative Research Centre 900, projects A2 and Z1, grant 158989968; Germany's Excellence Strategy - EXC 2155 "RESIST" - project ID 39087428) and the Bundesministerium für Bildung und Forschung (BMBF) (German Center for Lung Research, Disease Area Cystic Fibrosis at BREATH, grant 82DZL002A1).

The funders had no role in study design, data collection and analysis, decision to publish, or preparation of the manuscript.
1. Teweldemedhin $\mathrm{M}$, Gebreyesus $\mathrm{H}, \mathrm{Atsbaha} \mathrm{AH}$, et al.: Bacterial profile of ocular infections: a systematic review. BMC Ophthalmol. 2017; 17(1): 212. PubMed Abstract | Publisher Full Text | Free Full Text

2. Glik J, Łabuś W, Kitala D, et al: $\mathbf{2 0 0 0}$ patient retrospective assessment of a new strategy for burn wound management in view of infection prevention and treatment. Int Wound J. 2018; 15(3): 344-9. PubMed Abstract | Publisher Full Text

3. Koulenti D, Lisboa T, Brun-Buisson C, et al: Spectrum of practice in the diagnosis of nosocomial pneumonia in patients requiring mechanical ventilation in European intensive care units. Crit Care Med. 2009; 37(8): 2360-8. PubMed Abstract | Publisher Full Text

4. Maraolo AE, Cascella $\mathrm{M}$, Corcione $\mathrm{S}$, et al: Management of multidrug-resistant Pseudomonas aeruginosa in the intensive care unit: state of the art. Expert Rev Anti Infect Ther. 2017: 15(9): 861-71. PubMed Abstract | Publisher Full Text

5. Parkins MD, Somayaji R, Waters VJ: Epidemiology, Biology, and Impact of Clonal Pseudomonas aeruginosa Infections in Cystic Fibrosis. Clin Microbiol Rev. 2018; 31(4): pii: e00019-18.

PubMed Abstract | Publisher Full Text | Free Full Text

6. Wilson R, Aksamit T, Aliberti S, et al.: Challenges in managing Pseudomonas aeruginosa in non-cystic fibrosis bronchiectasis. Respir Med. 2016; 117: 179-89. PubMed Abstract | Publisher Full Text

7. Rohde GGU, Welte $\mathrm{T}$ : [Pseudomonas aeruginosa infections in chronic obstructive pulmonary disease: Role of long-term antibiotic treatment] Internist (Berl). 2017; 58(11): 1142-9. PubMed Abstract | Publisher Full Text

8. Balabanova Y, Gilsdorf A, Buda S, et al.: Communicable diseases prioritized for surveillance and epidemiological research: results of a standardized prioritization procedure in Germany, 2011. PLOS One. 2011; 6(10): e25691. PubMed Abstract | Publisher Full Text | Free Full Text

9. Lupo A, Haenni M, Madec JY: Antimicrobial Resistance in Acinetobacter spp. and Pseudomonas spp. Microbiol Spectr. 2018; 6(3) PubMed Abstract | Publisher Full Text

10. F Fajardo A, Martínez-Martín N, Mercadillo M, et al:: The neglected intrinsic resistome of bacterial pathogens. PLoS One. 2008; 3(2): e1619. PubMed Abstract | Publisher Full Text | Free Full Text | F1000 Recommendation
11. López-Causapé C, Cabot G, Del Barrio-Tofiño E, et al:: The Versatile Mutational Resistome of Pseudomonas aeruginosa. Front Microbiol. 2018; 9: 685. PubMed Abstract | Publisher Full Text | Free Full Text

12. Potron A, Poirel L, Nordmann P: Emerging broad-spectrum resistance in Pseudomonas aeruginosa and Acinetobacter baumannii: Mechanisms and epidemiology. Int J Antimicrob Agents. 2015; 45(6): 568-85. PubMed Abstract | Publisher Full Text

13. Eichenberger EM, Thaden JT: Epidemiology and Mechanisms of Resistance of Extensively Drug Resistant Gram-Negative Bacteria. Antibiotics (Basel). 2019; 8(2): pii: E37.

PubMed Abstract | Publisher Full Text | Free Full Text

14. Pérez A, Gato E, Pérez-Llarena J, et al:: High incidence of MDR and XDR Pseudomonas aeruginosa isolates obtained from patients with ventilatorassociated pneumonia in Greece, Italy and Spain as part of the MagicBullet clinical trial. J Antimicrob Chemother. 2019; 74(5): 1244-52. PubMed Abstract | Publisher Full Text

15. Del Barrio-Tofiño E, Zamorano L, Cortes-Lara S, et al: Spanish nationwide survey on Pseudomonas aeruginosa antimicrobial resistance mechanisms and epidemiology. J Antimicrob Chemother. 2019; 74(7): 1825-35. PubMed Abstract | Publisher Full Text

16. Carb-X Combating Antibiotic Resistant Bacteria. Carb-X, 2019. Reference Source

17. Olaitan AO, Morand S, Rolain JM: Mechanisms of polymyxin resistance: acquired and intrinsic resistance in bacteria. Front Microbiol. 2014; 5: 643. PubMed Abstract | Publisher Full Text | Free Full Text

18. $\mathrm{F}$ Jeannot $\mathrm{K}$, Bolard $\mathrm{A}$, Plésiat $\mathrm{P}$ : Resistance to polymyxins in Gram-negative organisms. Int J Antimicrob Agents. 2017; 49(5): 526-35. PubMed Abstract | Publisher Full Text | F1000 Recommendation

19. van Duin D, Bonomo RA: Ceftazidime/Avibactam and Ceftolozane/Tazobactam Second-generation $\beta$-Lactam/ $\beta$-Lactamase Inhibitor Combinations. Clin Infect Dis. 2016; 63(2): 234-41. PubMed Abstract | Publisher Full Text | Free Full Text

20. Evans SR, Tran TTT, Hujer AM, et al:: Rapid Molecular Diagnostics to Inform Empiric Use of Ceftazidime/Avibactam and Ceftolozane/Tazobactam Against Pseudomonas aeruginosa: PRIMERS IV. Clin Infect Dis. 2019; 68(11): 1823-30. PubMed Abstract | Publisher Full Text 
21. Sader HS, Flamm RK, Carvalhaes CG, et al.: Antimicrobial Susceptibility of Pseudomonas aeruginosa to Ceftazidime-Avibactam, Ceftolozane-Tazobactam, Piperacillin-Tazobactam, and Meropenem Stratified by U.S. Census Divisions: Results from the 2017 INFORM Program. Antimicrob Agents Chemother. 2018; 62(12): pii: e01587-18.

PubMed Abstract | Publisher Full Text | Free Full Text

22. Karlowsky JA, Kazmierczak KM, Bouchillon SK, et al.: In Vitro Activity of Ceftazidime-Avibactam against Clinical Isolates of Enterobacteriaceae and Pseudomonas aeruginosa Collected in Latin American Countries: Results from the INFORM Global Surveillance Program, 2012 to 2015. Antimicrob Agents Chemother. 2019; 63(4): pii: e01814-18.

PubMed Abstract | Publisher Full Text | Free Full Text

23. Schaumburg F, Bletz S, Mellmann A, et al.: Comparison of methods to analyse susceptibility of German MDR/XDR Pseudomonas aeruginosa to ceftazidime/avibactam. Int J Antimicrob Agents. 2019; 54(2): 255-260, pii: S09248579(19)30108-6.

PubMed Abstract | Publisher Full Text

24. Zamudio R, Hijazi K, Joshi C, et al:: Phylogenetic analysis of resistance to ceftazidime/avibactam, ceftolozane/tazobactam and carbapenems in piperacillin/tazobactam-resistant Pseudomonas aeruginosa from cystic fibrosis patients. Int J Antimicrob Agents. 2019: 53(6): 774-80.

PubMed Abstract | Publisher Full Text

25. Poirel L, Ortiz De La Rosa JM, Kieffer N, et al.: Acquisition of Extended-Spectrum $\beta$-Lactamase GES-6 Leading to Resistance to Ceftolozane-Tazobactam Combination in Pseudomonas aeruginosa. Antimicrob Agents Chemother. 2019; 63(1): pii: e01809-18

PubMed Abstract | Publisher Full Text | Free Full Text

26. Jean SS, Gould IM, Lee WS, et al:: New Drugs for Multidrug-Resistant GramNegative Organisms: Time for Stewardship. Drugs. 2019; 79(7): 705-14. PubMed Abstract | Publisher Full Text

27. Horner C, Mushtaq S, Livermore DM, et al.: Potentiation of imipenem by relebactam for Pseudomonas aeruginosa from bacteraemia and respiratory infections. J Antimicrob Chemother. 2019; 74(7): 1940-4. PubMed Abstract | Publisher Full Text

28. F Zhanel GG, Lawrence CK, Adam H, et al.: Imipenem-Relebactam and Meropenem-Vaborbactam: Two Novel Carbapenem- $\beta$-Lactamase Inhibitor Combinations. Drugs. 2018; 78(1): 65-98. PubMed Abstract | Publisher Full Text | F1000 Recommendation

29. F Karlowsky JA, Lob SH, Young K, et al:: Activity of imipenem/relebactam against $P$ seudomonas aeruginosa with antimicrobial-resistant phenotypes from seven global regions: SMART 2015-2016. J Glob Antimicrob Resist. 2018; 15: $140-7$.

PubMed Abstract | Publisher Full Text | F1000 Recommendation

30. Thomson KS, AbdelGhani S, Snyder JW, et al:: Activity of Cefepime-Zidebactam against Multidrug-Resistant (MDR) Gram-Negative Pathogens. Antibiotics (Basel). 2019; 8(1): pii: E32.

PubMed Abstract | Publisher Full Text | Free Full Text

31. Moya B, Barcelo IM, Bhagwat S, et al.: WCK 5107 (Zidebactam) and WCK 5153 Are Novel Inhibitors of PBP2 Showing Potent " $\beta$-Lactam Enhancer" Activity against $P$ seudomonas aeruginosa, Including Multidrug-Resistant Metallo- $\beta$ Lactamase-Producing High-Risk Clones. Antimicrob Agents Chemother. 2017; 61(6): pii: e02529-16.

PubMed Abstract | Publisher Full Text | Free Full Text

32. Okujava R, Garcia-Alcalde F, Haldimann A, et al.: 1359. Activity of Meropenem/ Nacubactam Combination Against Gram-Negative Clinical Isolates: ROSCO Global Surveillance 2017. Open Forum Infect Dis. 2018; 5(Suppl 1): S416. Publisher Full Text | Free Full Text

33. Daigle D, Hamrick J, Chatwin C, et al.: 1370. Cefepime/VNRX-5133 BroadSpectrum Activity Is Maintained Against Emerging KPC- and PDC-Variants in Multidrug-Resistant $K$. pneumoniae and $P$. aeruginosa. Open Forum Infect Dis. 2018; 5(Suppl 1): S419-S420.

Publisher Full Text | Free Full Tex

34. F Zhanel GG, Golden AR, Zelenitsky S, et al:: Cefiderocol: A Siderophore Cephalosporin with Activity Against Carbapenem-Resistant and MultidrugResistant Gram-Negative Bacilli. Drugs. 2019; 79(3): 271-89. PubMed Abstract | Publisher Full Text | F1000 Recommendation

35. Portsmouth $\mathrm{S}$, van Veenhuyzen D, Echols R, et al.: Cefiderocol versus imipenemcilastatin for the treatment of complicated urinary tract infections caused by Gram-negative uropathogens: a phase 2, randomised, double-blind, noninferiority trial. Lancet Infect Dis. 2018; 18(12): 1319-28. PubMed Abstract | Publisher Full Text

36. F Ito A, Nishikawa T, Matsumoto S, et al:: Siderophore Cephalosporin Cefiderocol Utilizes Ferric Iron Transporter Systems for Antibacterial Activity against Pseudomonas aeruginosa. Antimicrob Agents Chemother. 2016; 60(12): 7396-401.

PubMed Abstract | Publisher Full Text | Free Full Text | F1000 Recommendation

37. Ito A, Sato T, Ota M, et al:: In Vitro Antibacterial Properties of Cefiderocol, a Novel Siderophore Cephalosporin, against Gram-Negative Bacteria. Antimicrob Agents Chemother. 2018; 62(1): pii: e01454-17.

PubMed Abstract | Publisher Full Text | Free Full Text

38. Hsueh SC, Lee YJ, Huang YT, et al.: In vitro activities of cefiderocol, ceftolozane/tazobactam, ceftazidime/avibactam and other comparative drugs against imipenem-resistant $P$ seudomonas aeruginosa and Acinetobacter baumannii, and Stenotrophomonas maltophilia, all associated with bloodstream infections in Taiwan. J Antimicrob Chemother. 2019; 74(2): 380-6. PubMed Abstract | Publisher Full Text

39. Ito A, Nishikawa $\mathrm{T}$, Ota $\mathrm{M}$, et al:: Stability and low induction propensity of cefiderocol against chromosomal AmpC $\beta$-lactamases of Pseudomonas aeruginosa and Enterobacter cloacae. J Antimicrob Chemother. 2019; 74(2): 539. PubMed Abstract | Publisher Full Text | Free Full Text

40. Jacobs MR, Abdelhamed AM, Good CE, et al:: ARGONAUT-I: Activity of Cefiderocol (S-649266), a Siderophore Cephalosporin, against GramNegative Bacteria, Including Carbapenem-Resistant Nonfermenters and Enterobacteriaceae with Defined Extended-Spectrum $\beta$-Lactamases and Carbapenemases. Antimicrob Agents Chemother. 2018; 63(1): pii: e01801-18. PubMed Abstract | Publisher Full Text | Free Full Text

41. Kazmierczak KM, Tsuji M, Wise MG, et al.: In vitro activity of cefiderocol, a siderophore cephalosporin, against a recent collection of clinically relevant carbapenem-non-susceptible Gram-negative bacilli, including serine carbapenemase- and metallo- $\beta$-lactamase-producing isolates (SIDERO-WT2014 Study). Int J Antimicrob Agents. 2019; 53(2): 177-84. PubMed Abstract | Publisher Full Tex

42. Voulgaris GL, Voulgari ML, Falagas ME: Developments on antibiotics for multidrug resistant bacterial Gram-negative infections. Expert Rev Anti Infect Ther. 2019; 17(6): 387-401.

PubMed Abstract | Publisher Full Text

43. Stubbings W, Leow P, Yong GC, et al.: In vitro spectrum of activity of finafloxacin, a novel, pH-activated fluoroquinolone, under standard and acidic conditions. Antimicrob Agents Chemother. 2011; 55(9): 4394-7. PubMed Abstract | Publisher Full Text | Free Full Text

44. Ocheretyaner ER, Park TE: Delafloxacin: a novel fluoroquinolone with activity against methicillin-resistant Staphylococcus aureus (MRSA) and Pseudomonas aeruginosa. Expert Rev Anti Infect Ther. 2018; 16(7): 523-30. PubMed Abstract | Publisher Full Text

45. Tulkens PM, Van Bambeke F, Zinner SH: Profile of a Novel Anionic Fluoroquinolone-Delafloxacin. Clin Infect Dis. 2019; 68(Supplement_3): S213-S222. PubMed Abstract | Publisher Full Text | Free Full Text

46. F Andolina G, Bencze LC, Zerbe K, et al:: A Peptidomimetic Antibiotic Interacts with the Periplasmic Domain of LptD from Pseudomonas aeruginosa. ACS Chem Biol. 2018; 13(3): 666-75.

PubMed Abstract | Publisher Full Text | F1000 Recommendation

47. Sader HS, Dale GE, Rhomberg PR, et al:: Antimicrobial Activity of Murepavadin Tested against Clinical Isolates of Pseudomonas aeruginosa from the United States, Europe, and China. Antimicrob Agents Chemother. 2018; 62(7): pii: e00311-18. PubMed Abstract | Publisher Full Text | Free Full Text

48. F Sader HS, Flamm RK, Dale GE, et al:: Murepavadin activity tested against contemporary (2016-17) clinical isolates of XDR Pseudomonas aeruginosa. $J$ Antimicrob Chemother. 2018; 73(9): 2400-4.

PubMed Abstract | Publisher Full Text | F1000 Recommendation

49. Gorr SU, Flory CM, Schumacher RJ: In vivo activity and low toxicity of the second-generation antimicrobial peptide DGL13K. PLOS One. 2019; 14(5): e0216669.

PubMed Abstract | Publisher Full Text | Free Full Text

50. Yasir M, Dutta D, Willcox MDP: Comparative mode of action of the antimicrobial peptide melimine and its derivative Mel4 against $P$ seudomonas aeruginosa. Sci Rep. 2019; 9(1): 7063.

PubMed Abstract | Publisher Full Text | Free Full Text

51. Romoli O, Mukherjee S, Mohid SA, et al:: Enhanced Silkworm Cecropin B Antimicrobial Activity against Pseudomonas aeruginosa from Single Amino Acid Variation. ACS Infect Dis. 2019; 5(7): 1200-13. PubMed Abstract | Publisher Full Text

52. Molchanova N, Wang $\mathrm{H}$, Hansen PR, et al: Antimicrobial Activity of $\alpha$ Peptide//-Peptoid Lysine-Based Peptidomimetics Against Colistin-Resistant Pseudomonas aeruginosa Isolated From Cystic Fibrosis Patients. Front Microbiol. 2019; 10: 275.

PubMed Abstract | Publisher Full Text | Free Full Text

53. Cândido ES, Cardoso MH, Chan LY, et al:: Short Cationic Peptide Derived from Archaea with Dual Antibacterial Properties and Anti-Infective Potential. ACS Infect. Dis. 2019; 5(7): 1081-1086. PubMed Abstract | Publisher Full Text

54. Kang HK, Seo CH, Luchian T, et al:: Pse-T2, an Antimicrobial Peptide with High-Level, Broad-Spectrum Antimicrobial Potency and Skin Biocompatibility against Multidrug-Resistant Pseudomonas aeruginosa Infection. Antimicrob Agents Chemother. 2018; 62(12): pii: e01493-18. PubMed Abstract | Publisher Full Text | Free Full Text

55. Beaudoin T, Stone TA, Glibowicka M, et al:: Activity of a novel antimicrobial peptide against Pseudomonas aeruginosa biofilms. Sci Rep. 2018; 8(1): 14728. PubMed Abstract | Publisher Full Text | Free Full Text

56. Akbari R, Hakemi Vala M, Hashemi A, et al.: Action mechanism of melittinderived antimicrobial peptides, MDP1 and MDP2, de novo designed against multidrug resistant bacteria. Amino Acids. 2018; 50(9): 1231-43. PubMed Abstract | Publisher Full Text

57. F Ramsey BW, Dorkin HL, Eisenberg JD, et al.: Efficacy of Aerosolized 
Tobramycin in Patients with Cystic Fibrosis. N Engl J Med. 1993; 328(24): 1740-6.

PubMed Abstract | Publisher Full Text | F1000 Recommendation

58. Shteinberg M, Elborn JS: Use of inhaled tobramycin in cystic fibrosis. Adv Ther 2015; 32(1): 1-9.

PubMed Abstract | Publisher Full Text

59. Vardakas KZ, Voulgaris GL, Samonis G, et al:: Inhaled colistin monotherapy for respiratory tract infections in adults without cystic fibrosis: A systematic review and meta-analysis. Int J Antimicrob Agents. 2018; 51(1): 1-9. PubMed Abstract | Publisher Full Text

60. Koerner-Rettberg C, Ballmann M: Colistimethate sodium for the treatment of chronic pulmonary infection in cystic fibrosis: An evidence-based review of its place in therapy. Core Evid. 2014; 9: 99-112.

PubMed Abstract | Publisher Full Text | Free Full Text

61. Conole D, Keating GM: Colistimethate sodium dry powder for inhalation: A review of its use in the treatment of chronic Pseudomonas aeruginosa infection in patients with cystic fibrosis. Drugs. 2014; 74(3): 377-87. PubMed Abstract | Publisher Full Text

62. McCoy KS, Quittner AL, Oermann CM, et al.: Inhaled Aztreonam Lysine for Chronic Airway Pseudomonas aeruginosa in Cystic Fibrosis. Am J Respir Crit Care Med. 2008; 178(9): 921-8.

PubMed Abstract | Publisher Full Text | Free Full Text

63. Oermann CM, Retsch-Bogart GZ, Quittner AL, et al.: An 18-month study of the safety and efficacy of repeated courses of inhaled aztreonam lysine in cystic fibrosis. Pediatr Pulmonol. 2010; 45(11): 1121-34. PubMed Abstract | Publisher Full Text | Free Full Text

64. Elson EC, Mermis J, Polineni D, et al:: Aztreonam Lysine Inhalation Solution in Cystic Fibrosis. Clin Med Insights Circ Respir Pulm Med. 2019; 13: 1179548419842822

PubMed Abstract | Publisher Full Text | Free Full Text

65. Ehsan Z, Clancy JP: Management of Pseudomonas aeruginosa infection in cystic fibrosis patients using inhaled antibiotics with a focus on nebulized liposomal amikacin. Future Microbiol. 2015; 10(12): 1901-12. PubMed Abstract | Publisher Full Text | Free Full Text

66. F Aksamit T, de Soyza A, Bandel TJ, et al:: RESPIRE 2: A phase III placebocontrolled randomised trial of ciprofloxacin dry powder for inhalation in noncystic fibrosis bronchiectasis. Eur Respir J. 2018; 51(1): pii: 1702053. PubMed Abstract | Publisher Full Text | F1000 Recommendation

67. F de Soyza A, Aksamit T, Bandel TJ, et al.: RESPIRE 1: A phase III placebocontrolled randomised trial of ciprofloxacin dry powder for inhalation in noncystic fibrosis bronchiectasis. Eur Respir J. 2018; 51(1): pii: 1702052. PubMed Abstract | Publisher Full Text | F1000 Recommendation

68. VanDevanter DR, Gonda I, Dahms J, et al:: Microbiological changes observed over 48 weeks of treatment with inhaled liposomal ciprofloxacin in individuals with non-cystic fibrosis bronchiectasis and chronic Pseudomonas aeruginosa lung infection. Clin Microbiol Infect. 2019; pii: S1198-743X(19)30194-6. PubMed Abstract | Publisher Full Text

69. Haworth CS, Bilton D, Chalmers JD, et al.: Inhaled liposomal ciprofloxacin in patients with non-cystic fibrosis bronchiectasis and chronic lung infection with Pseudomonas aeruginosa (ORBIT-3 and ORBIT-4): Two phase 3, randomised controlled trials. Lancet Respir Med. 2019; 7(3): 213-26. PubMed Abstract | Publisher Full Text

70. Derbali RM, Aoun V, Moussa G, et al:: Tailored Nanocarriers for the Pulmonary Delivery of Levofloxacin against Pseudomonas aeruginosa: A Comparative Study. Mol Pharm. 2019; 16(5): 1906-16.

PubMed Abstract | Publisher Full Text

71. Clancy JP, Dupont L, Konstan MW, et al.: Phase II studies of nebulised Arikace in CF patients with Pseudomonas aeruginosa infection. Thorax. 2013; 68(9): 818-25

PubMed Abstract | Publisher Full Text | Free Full Text

72. F Chotirmall SH, Chalmers JD: RESPIRE: breathing new life into bronchiectasis. Eur Respir J. 2018; 51(1): pii: 1702444. PubMed Abstract | Publisher Full Text | F1000 Recommendation

73. F Pamp SJ, Gjermansen M, Johansen HK, et al:: Tolerance to the antimicrobial peptide colistin in Pseudomonas aeruginosa biofilms is linked to metabolically active cells, and depends on the pmr and mexAB-oprM genes. Mol Microbiol. 2008; 68(1): 223-40.

PubMed Abstract | Publisher Full Text | F1000 Recommendation

74. Herrmann G, Yang L, Wu H, et al.: Colistin-Tobramycin Combinations Are Superior to Monotherapy Concerning the Killing of Biofilm Pseudomonas aeruginosa. J Infect Dis. 2010; 202(10): 1585-92. PubMed Abstract | Publisher Full Text

75. Riethmüller J, Herrmann G, Graepler-Mainka U, et al:: Sequential Inhalational Tobramycin-Colistin-Combination in CF-Patients with Chronic $P$. Aeruginosa Colonization - an Observational Study. Cell Physiol Biochem. 2016; 39(3): 1141-51. PubMed Abstract | Publisher Full Text

76. Rojo-Molinero E, Macià MD, Rubio R, et al:: Sequential Treatment of Biofilms with Aztreonam and Tobramycin Is a Novel Strategy for Combating Pseudomonas aeruginosa Chronic Respiratory Infections. Antimicrob Agents Chemother. 2016 60(5): 2912-22.

PubMed Abstract | Publisher Full Text | Free Full Text

77. Tschudin-Sutter S, Fosse N, Frei R, et al.: Combination therapy for treatment of Pseudomonas aeruginosa bloodstream infections. PLOS One. 2018; 13(9): e0203295.

PubMed Abstract | Publisher Full Text | Free Full Text

78. Jiao Y, Moya B, Chen MJ, et al.: Comparable Efficacy and Better Safety of Double $\beta$-Lactam Combination Therapy versus $\beta$-Lactam plus Aminoglycoside in Gram-Negative Bacteria in Randomized, Controlled Trials. Antimicrob Agents Chemother. 2019; 63(7): pii: e00425-19.

PubMed Abstract | Publisher Full Text | Free Full Text

79. F Vaara M, Vaara T: Sensitization of Gram-negative bacteria to antibiotics and complement by a nontoxic oligopeptide. Nature. 1983; 303(5917): 526-8. PubMed Abstract | Publisher Full Text | F1000 Recommendation

80. Kubesch P, Wehsling M, Tümmler B: Membrane permeability of Pseudomonas aeruginosa to 4-quinolones. Zentralbl Bakteriol Mikrobiol Hyg A. 1987; 265(1-2) 197-202.

PubMed Abstract | Publisher Full Text

81. Stokes JM, MacNair CR, llyas B, et al.: Pentamidine sensitizes Gram-negative pathogens to antibiotics and overcomes acquired colistin resistance. Nat Microbiol. 2017; 2: 17028.

PubMed Abstract | Publisher Full Text | Free Full Text

82. Corbett D, Wise A, Langley T, et al:: Potentiation of Antibiotic Activity by a Novel Cationic Peptide: Potency and Spectrum of Activity of SPR741. Antimicrob Agents Chemother. 2017; 61(8): pii: e00200-17.

PubMed Abstract | Publisher Full Text | Free Full Text

83. F Vaara M: Polymyxin Derivatives that Sensitize Gram-Negative Bacteria to Other Antibiotics. Molecules. 2019; 24(2): pii: E249.

PubMed Abstract | Publisher Full Text | Free Full Text | F1000 Recommendation

84. F Schütz C, Empting M: Targeting the Pseudomonas quinolone signal quorum sensing system for the discovery of novel anti-infective pathoblockers. Beilstein J Org Chem. 2018; 14: 2627-45.

PubMed Abstract | Publisher Full Text | Free Full Text | F1000 Recommendation

85. Soheili V, Tajani AS, Ghodsi R, et al: Anti-PqsR compounds as next-generation antibacterial agents against Pseudomonas aeruginosa: A review. Eur $\mathrm{J} M e d$ Chem. 2019; 172: 26-35.

PubMed Abstract | Publisher Full Text

86. Welsh MA, Blackwell HE: Chemical probes of quorum sensing: from compound development to biological discovery. FEMS Microbiol Rev. 2016; 40(5): 774-94. PubMed Abstract | Publisher Full Text | Free Full Text

87. Defoirdt T: Quorum-Sensing Systems as Targets for Antivirulence Therapy. Trends Microbiol. 2018; 26(4): 313-28.

PubMed Abstract | Publisher Full Text

88. F Kudoh S, Uetake T, Hagiwara K, et al:: [Clinical effects of low-dose longterm erythromycin chemotherapy on diffuse panbronchiolitis]. Nihon Kyobu Shikkan Gakkai Zasshi. 1987; 25(6): 632-42. PubMed Abstract | Publisher Full Text | F1000 Recommendation

89. Tateda K, Comte R, Pechere JC, et al:: Azithromycin inhibits quorum sensing in Pseudomonas aeruginosa. Antimicrob Agents Chemother. 2001; 45(6): 1930-3. PubMed Abstract | Publisher Full Text | Free Full Text

90. $\mathrm{F}$ van Delden C, Köhler T, Brunner-Ferber F, et al:: Azithromycin to prevent Pseudomonas aeruginosa ventilator-associated pneumonia by inhibition of quorum sensing: a randomized controlled trial. Intensive Care Med. 2012; 38(7): $1118-25$.

PubMed Abstract | Publisher Full Text | F1000 Recommendation

91. $\mathrm{F}$ Kaneko $\mathrm{Y}$, Thoendel M, Olakanmi O, et al.: The transition metal gallium disrupts Pseudomonas aeruginosa iron metabolism and has antimicrobial and antibiofilm activity. J Clin Invest. 2007; 117(4): 877-88.

PubMed Abstract | Publisher Full Text | Free Full Text | F1000 Recommendation

92. DeLeon $\mathrm{K}$, Balldin $\mathrm{F}$, Watters $\mathrm{C}$, et al: Gallium maltolate treatment eradicates Pseudomonas aeruginosa infection in thermally injured mice. Antimicrob Agents Chemother. 2009; 53(4): 1331-7.

PubMed Abstract | Publisher Full Text | Free Full Text

93 Yeterian E, Martin LW, Lamont IL, et al:: An efflux pump is required for siderophore recycling by Pseudomonas aeruginosa. Environ Microbiol Rep. 2010; 2(3): 412-8.

PubMed Abstract | Publisher Full Text

94. Halwani M, Yebio B, Suntres ZE, et al:: Co-encapsulation of gallium with gentamicin in liposomes enhances antimicrobial activity of gentamicin against Pseudomonas aeruginosa. J Antimicrob Chemother. 2008; 62(6): 1291-7. PubMed Abstract | Publisher Full Text

95. $\mathrm{F}$ Goss $\mathrm{CH}$, Kaneko $\mathrm{Y}, \mathrm{Khuu} \mathrm{L}$, et al.: Gallium disrupts bacterial iron metabolism and has therapeutic effects in mice and humans with lung infections. Sci Transl Med. 2018; 10(460): pii: eaat7520.

PubMed Abstract | Publisher Full Text | Free Full Text | F1000 Recommendation

96. Bowlin NO, Williams JD, Knoten CA, et al:: Mutations in the Pseudomonas aeruginosa needle protein gene $p s c F$ confer resistance to phenoxyacetamide inhibitors of the type III secretion system. Antimicrob Agents Chemother. 2014; 58(4): 2211-20

PubMed Abstract | Publisher Full Text | Free Full Text

97. Berube BJ, Murphy KR, Torhan MC, et al.: Impact of Type III Secretion Effectors and of Phenoxyacetamide Inhibitors of Type III Secretion on Abscess Formation in a Mouse Model of Pseudomonas aeruginosa Infection. Antimicrob 
Agents Chemother. 2017; 61(11): pii: e01202-17. PubMed Abstract | Publisher Full Text | Free Full Text

98. F Frank DW, Vallis A, Wiener-Kronish JP, et al:: Generation and characterization of a protective monoclonal antibody to Pseudomonas aeruginosa PcrV. J Infect Dis. 2002; 186(1): 64-73. PubMed Abstract | Publisher Full Text | F1000 Recommendation

99. F Jain R, Beckett VV, Konstan MW, et al.: KB001-A, a novel anti-inflammatory, found to be safe and well-tolerated in cystic fibrosis patients infected with Pseudomonas aeruginosa. J Cyst Fibros. 2018; 17(4): 484-91. PubMed Abstract | Publisher Full Text | F1000 Recommendation

100. Tabor DE, Oganesyan V, Keller AE, et al:: Pseudomonas aeruginosa PcrV and Psl, the Molecular Targets of Bispecific Antibody MEDI3902, Are Conserved Among Diverse Global Clinical Isolates. J Infect Dis. 2018; 218(12): 1983-94. PubMed Abstract | Publisher Full Text

101. F Thanabalasuriar A, Surewaard BG, Willson ME, et al.: Bispecific antibody targets multiple Pseudomonas aeruginosa evasion mechanisms in the lung vasculature. J Clin Invest. 2017; 127(6): 2249-61.

PubMed Abstract | Publisher Full Text | Free Full Text | F1000 Recommendation

102. Ali SO, Yu XQ, Robbie GJ, et al.: Phase 1 study of MEDI3902, an investigationa anti-Pseudomonas aeruginosa PcrV and Psl bispecific human monoclonal antibody, in healthy adults. Clin Microbiol Infect. 2019; 25(5): 629.e1-629.e6. PubMed Abstract | Publisher Full Text

103. Tran TT, Yu H, Vidaillac $\mathrm{C}$, et al:: An evaluation of inhaled antibiotic liposome versus antibiotic nanoplex in controlling infection in bronchiectasis. Int $J$ Pharm. 2019; 559: 382-92.

PubMed Abstract | Publisher Full Text

104. Tran TT, Vidaillac $\mathrm{C}, \mathrm{Yu} \mathrm{H}$, et al:: A new therapeutic avenue for bronchiectasis: Dry powder inhaler of ciprofloxacin nanoplex exhibits superior ex vivo mucus permeability and antibacterial efficacy to its native ciprofloxacin counterpart. Int J Pharm. 2018; 547(1-2): 368-76. PubMed Abstract | Publisher Full Text

105. Wang S, Yu S, Lin Y, et al.: Co-Delivery of Ciprofloxacin and Colistin in Liposomal Formulations with Enhanced In Vitro Antimicrobial Activities against Multidrug Resistant Pseudomonas aeruginosa. Pharm Res. 2018; 35(10): 187

PubMed Abstract | Publisher Full Text | Free Full Text

106. Zahra MJ, Hamed H, Mohammad RY, et al: Evaluation and study of antimicrobial activity of nanoliposomal meropenem against Pseudomonas aeruginosa isolates. Artif Cells Nanomed Biotechnol. 2017; 45(5): 975-80. PubMed Abstract | Publisher Full Text

107. Dai X, Zhao Y, Yu Y, et al: All-in-one NIR-activated nanoplatforms for enhanced bacterial biofilm eradication. Nanoscale. 2018; 10(39): 18520-30. PubMed Abstract | Publisher Full Text

108. Bahamondez-Canas TF, Ferrati S, Moraga-Espinoza DF, et al.: Development, Characterization, and In Vitro Testing of Co-Delivered Antimicrobial Dry Powder Formulation for the Treatment of Pseudomonas aeruginosa Biofilms. J Pharm Sci. 2018; 107(8): 2172-8. PubMed Abstract | Publisher Full Text

109. Alhariri M, Majrashi MA, Bahkali AH, et al.: Efficacy of neutral and negatively charged liposome-loaded gentamicin on planktonic bacteria and biofilm communities. Int J Nanomedicine. 2017; 12: 6949-61. PubMed Abstract | Publisher Full Text | Free Full Text

110. Hill M, Cunningham RN, Hathout RM, et al:: Formulation of Antimicrobial Tobramycin Loaded PLGA Nanoparticles via Complexation with AOT. J Funct Biomater. 2019; 10(2): pii: E26. PubMed Abstract | Publisher Full Text | Free Full Text

111. Shaaban MI, Shaker MA, Mady FM: Imipenem/cilastatin encapsulated polymeric nanoparticles for destroying carbapenem-resistant bacterial isolates. J Nanobiotechnology. 2017; 15(1): 29 .

PubMed Abstract | Publisher Full Text | Free Full Text

112. Li R, Yuan X, Wei J, et al:: Synthesis and Evaluation of a Chitosan Oligosaccharide-Streptomycin Conjugate against $P$ seudomonas aeruginosa Biofilms. Mar Drugs. 2019; 17(1): pii: E43. PubMed Abstract | Publisher Full Text | Free Full Text

113. Pushparaj Selvadoss $\mathrm{P}$, Nellore J, Balaraman Ravindrran M, et al.: Enhancement of antimicrobial activity by liposomal oleic acid-loaded antibiotics for the treatment of multidrug-resistant Pseudomonas aeruginosa. Artif Cells Nanomed Biotechnol. 2018; 46(2): 268-73. PubMed Abstract | Publisher Full Tex

114. Severino P, Silveira EF, Loureiro K, et al:: Antimicrobial activity of polymyxin-loaded solid lipid nanoparticles (PLX-SLN): Characterization of physicochemical properties and in vitro efficacy. Eur J Pharm Sci. 2017; 106 $177-84$.

PubMed Abstract | Publisher Full Text

115. Chang RYK, Chen K, Wang J, et al.: Proof-of-Principle Study in a Murine Lung Infection Model of Antipseudomonal Activity of Phage PEV20 in a Dry-Powder Formulation. Antimicrob Agents Chemother. 2018; 62(2): pii: e01714-17. PubMed Abstract | Publisher Full Text | Free Full Text

116. Alvarado-Gomez E, Martínez-Castañon G, Sanchez-Sanchez R, et al:: Evaluation of anti-biofilm and cytotoxic effect of a gel formulation with Pluronic F-127 and silver nanoparticles as a potential treatment for skin wounds. Mater Sci Eng C Mater Biol Appl. 2018; 92: 621-30. PubMed Abstract | Publisher Full Text
117. Kłodzińska SN, Molchanova N, Franzyk $\mathrm{H}$, et al.: Biopolymer nanogels improve antibacterial activity and safety profile of a novel lysine-based $\alpha$-peptide/ $\beta$ peptoid peptidomimetic. Eur J Pharm Biopharm. 2018; 128: 1-9. PubMed Abstract | Publisher Full Text

118. Anjum A, Sim CH, Ng SF: Hydrogels Containing Antibiofilm and Antimicrobial Agents Beneficial for Biofilm-Associated Wound Infection: Formulation Characterizations and In vitro Study. AAPS PharmSciTech. 2018; 19(3): 1219-30. PubMed Abstract | Publisher Full Text

119. Gil J, Natesan S, Li J, et al:: A PEGylated fibrin hydrogel-based antimicrobial wound dressing controls infection without impeding wound healing. Int Wound $\mathrm{J}$. 2017; 14(6): 1248-57.

PubMed Abstract | Publisher Full Text

120. Kalan LR, Pepin DM, Ul-Haq I, et al:: Targeting biofilms of multidrug-resistant bacteria with silver oxynitrate. Int J Antimicrob Agents. 2017; 49(6): 719-26. PubMed Abstract | Publisher Full Text

121. Cryz SJ Jr, Lang A, Rüdeberg $A$, et al:: Immunization of cystic fibrosis patients with a Pseudomonas aeruginosa O-polysaccharide-toxin A conjugate vaccine. Behring Inst Mitt. 1997; (98): 345-9. PubMed Abstract

122. F Döring G, Meisner C, Stern M: A double-blind randomized placebocontrolled phase III study of a Pseudomonas aeruginosa flagella vaccine in cystic fibrosis patients. Proc Natl Acad Sci U S A. 2007; 104(26): 11020-5. PubMed Abstract | Publisher Full Text | Free Full Text | F1000 Recommendation

123. Baumann U, Mansouri E, von Specht BU: Recombinant OprF-Oprl as a vaccine against Pseudomonas aeruginosa infections. Vaccine. 2004; 22(7): 840-7. PubMed Abstract | Publisher Full Text

124. Bumann D, Behre $C$, Behre $K$, et al: Systemic, nasal and oral live vaccines against $P$ seudomonas aeruginosa: a clinical trial of immunogenicity in lower airways of human volunteers. Vaccine. 2010; 28(3): 707-13. PubMed Abstract | Publisher Full Text

125. F Rello J, Krenn CG, Locker G, et al:: A randomized placebo-controlled phase II study of a Pseudomonas vaccine in ventilated ICU patients. Crit Care. 2017; 21: 22 . PubMed Abstract | Publisher Full Text | Free Full Text | F1000 Recommendation

126. Aguilera-Herce J, García-Quintanilla M, Romero-Flores R, et al.: A Live Salmonella Vaccine Delivering PcrV through the Type III Secretion System Protects against Pseudomonas aeruginosa. mSphere. 2019; 4(2): pii: e00116-19. PubMed Abstract | Publisher Full Text | Free Full Text

127. Cabral MP, García P, Beceiro A, et al.: Design of live attenuated bacterial vaccines based on D-glutamate auxotrophy. Nat Commun. 2017; 8: 15480 PubMed Abstract | Publisher Full Text | Free Full Text

128. Elhosary MA, Bahey-El-Din M, AbdelBary A, et al.: Immunization with the ferric iron-binding periplasmic protein HitA provides protection against Pseudomonas aeruginosa in the murine infection model. Microb Pathog. 2019; 131: $181-5$ PubMed Abstract | Publisher Full Text

129. Bianconi I, Alcalá-Franco B, Scarselli M, et al: Genome-Based Approach Delivers Vaccine Candidates Against Pseudomonas aeruginosa. Front Immunol. 2019; 9: 3021

PubMed Abstract | Publisher Full Text | Free Full Text

130. Naito $Y$, Hamaoka S, Kinoshita $M$, et al: The protective effects of nasal PcrV-CpG oligonucleotide vaccination against $P$ seudomonas aeruginosa pneumonia. Microbiol Immunol. 2018; 62(12): 774-85. PubMed Abstract | Publisher Full Tex

131. Gholami M, Salimi Chirani A, Falak R, et al.: Induction of Specific Humoral Immune Response in Mice against a Pseudomonas aeruginosa Chimeric PilQ/ PilA Protein. Rep Biochem Mol Biol. 2018; 7(1): 38-44. PubMed Abstract | Free Full Text

132. Kutateladze M, Adamia R: Bacteriophages as potential new therapeutics to replace or supplement antibiotics. Trends Biotechnol. 2010; 28(12): 591-5. PubMed Abstract | Publisher Full Text

133. $\mathrm{F}$ Kutateladze $\mathrm{M}$, Adamia R: Phage therapy experience at the Eliava Institute. Med Mal Infect 2008; 38(8): 426-30. PubMed Abstract | Publisher Full Text | F1000 Recommendation

134. Villarroel J, Larsen M, Kilstrup M, et al.: Metagenomic Analysis of Therapeutic PYO Phage Cocktails from 1997 to 2014. Viruses. 2017; 9(11): pii: E328. PubMed Abstract | Publisher Full Text | Free Full Text

135. Jennes $S$, Merabishvili $M$, Soentjens $P$, et al.: Use of bacteriophages in the treatment of colistin-only-sensitive Pseudomonas aeruginosa septicaemia in a patient with acute kidney injury-a case report. Crit Care. 2017; 21(1): 129. PubMed Abstract | Publisher Full Text | Free Full Text

136. Furr CLL, Lehman SM, Morales SP, et al.: P084 Bacteriophage treatment of multidrug-resistant $P$ seudomonas aeruginosa pneumonia in a cystic fibrosis patient. J Cyst Fibros. 2018; 17(Supplement 3): S83. Publisher Full Text

137. $F$ Jault $P$, Leclerc $T$, Jennes $S$, et al: Efficacy and tolerability of a cocktail of bacteriophages to treat burn wounds infected by Pseudomonas aeruginosa (PhagoBurn): A randomised, controlled, double-blind phase 1/2 trial. Lancet Infect Dis. 2019; 19(1): 35-45. PubMed Abstract | Publisher Full Text | F1000 Recommendation

138. Liu L, Liu B, Li Y, et al:: Successful control of resistance in Pseudomonas aeruginosa using antibiotic stewardship and infection control programs at 
a Chinese university hospital: a 6-year prospective study. Infect Drug Resist. 2018; 11: 637-46.

PubMed Abstract | Publisher Full Text | Free Full Text

139. Lewis RH, Sharpe JP, Swanson JM, et al:: Reinventing the wheel: Impact of prolonged antibiotic exposure on multidrug-resistant ventilator-associated pneumonia in trauma patients. J Trauma Acute Care Surg. 2018; 85(2): 256-62. PubMed Abstract | Publisher Full Text

140. Döring G: Prevention of Pseudomonas aeruginosa infection in cystic fibrosis patients. Int J Med Microbiol. 2010; 300(8): 573-7.

PubMed Abstract | Publisher Full Text

141. Garvey ML, Bradley CW, Holden E: Waterborne Pseudomonas aeruginosa transmission in a hematology unit? Am J Infect Control. 2018; 46(4): 383-6. PubMed Abstract | Publisher Full Text

142. Kumarage J, Khonyongwa $\mathrm{K}$, Khan A, et al:: Transmission of multi-drug resistant Pseudomonas aeruginosa between two flexible ureteroscopes and an outbreak of urinary tract infection: the fragility of endoscope decontamination. $J$ Hosp Infect. 2019; 102(1): 89-94. PubMed Abstract | Publisher Full Text

143. Wiehlmann L, Cramer N, Ulrich J, et al.: Effective prevention of Pseudomonas aeruginosa cross-infection at a cystic fibrosis centre - results of a 10-year prospective study. Int J Med Microbiol. 2012; 302(2): 69-77. PubMed Abstract | Publisher Full Text

144. Cramer N, Wiehlmann L, Tümmler B: Clonal epidemiology of Pseudomonas aeruginosa in cystic fibrosis. Int J Med Microbiol. 2010; 300(8): 526-33. PubMed Abstract | Publisher Full Text
145. Saiman L, Siegel JD, LiPuma JJ, et al.: Infection prevention and control guideline for cystic fibrosis: 2013 update. Infect Control Hosp Epidemiol. 2014 35 Suppl 1: S1-S67.

PubMed Abstract | Publisher Full Text

146. F Robak OH, Heimesaat MM, Kruglov AA, et al:: Antibiotic treatmentinduced secondary IgA deficiency enhances susceptibility to Pseudomonas aeruginosa pneumonia. J Clin Invest. 2018; 128(8): 3535-45.
PubMed Abstract | Publisher Full Text | Free Full Text | F1000 Recommendation

147. $\mathrm{F}$ Ackermann M, Kempf $\mathrm{H}$, Hetzel M, et al:: Bioreactor-based mass production of human iPSC-derived macrophages enables immunotherapies against bacterial airway infections. Nat Commun. 2018; 9(1): 5088 PubMed Abstract | Publisher Full Text | Free Full Text | F1000 Recommendation

148. Rasmussen TB, Bjarnsholt T, Skindersoe ME, et al.: Screening for quorumsensing inhibitors (QSI) by use of a novel genetic system, the QSI selector. J Bacteriol. 2005; 187(5): 1799-814. PubMed Abstract | Publisher Full Text | Free Full Text

149. García-Contreras R, Pérez-Eretza B, Lira-Silva E, et al.: Gallium induces the production of virulence factors in Pseudomonas aeruginosa. Pathog Dis. 2014; 70(1): 95-8

PubMed Abstract | Publisher Full Text

150. F Dedrick RM, Guerrero-Bustamante CA, Garlena RA, et al.: Engineered bacteriophages for treatment of a patient with a disseminated drug-resistant Mycobacterium abscessus. Nat Med. 2019; 25(5): 730-3.

PubMed Abstract | Publisher Full Text | Free Full Text | F1000 Recommendation 


\section{Open Peer Review}

\section{Current Peer Review Status:}

\section{Editorial Note on the Review Process}

Faculty Reviews are review articles written by the prestigious Members of Faculty Opinions. The articles are commissioned and peer reviewed before publication to ensure that the final, published version is comprehensive and accessible. The reviewers who approved the final version are listed with their names and affiliations.

\section{The reviewers who approved this article are:}

\section{Version 1}

\section{Antonio Oliver}

Servicio de Microbiología Módulo J, segundo piso, Hospital Universitario Son Espases, Instituto de Investigación Sanitaria Illes Balears (IdISBa), Palma de Mallorca, Spain

Competing Interests: No competing interests were disclosed.

2. José Luis Martinez-Menendez

Department of Microbial Biotechnology, CNB - Spanish National Centre for Biotechnology, Madrid, Spain

Competing Interests: No competing interests were disclosed.

The benefits of publishing with F1000Research:

- Your article is published within days, with no editorial bias

- You can publish traditional articles, null/negative results, case reports, data notes and more

- The peer review process is transparent and collaborative

- Your article is indexed in PubMed after passing peer review

- Dedicated customer support at every stage

For pre-submission enquiries, contact research@f1000.com 